\title{
Topical Ozone Therapy in the Treatment of Pharmacodermia in a Dog (Canis lupus familiaris)
}

\author{
José Ivaldo de Siqueira Silva Júnior', Caio Simon Florêncio dos Santos², Bruna Martins da Silva', \\ Ivan Felismino Charas dos Santos ${ }^{3}$, Barbara Sardela Ferro', Talyta Isly Silva Barros², \\ Rubia Mitalli Tomacheuski ${ }^{5}$ \& Lucilene Simões-Mattos ${ }^{6}$
}

\begin{abstract}
Background: Pharmacodermia is a drug reaction that manifests itself on the skin and mucous membranes. The main drugs that cause pharmacodermia are $\beta$-lactam antibiotics. It has a rare occurrence in dogs and may present different clinical signs. Ozone therapy is used to treat various conditions, such as infections and inflammatory diseases. This therapy acts through oxidative stress generating a positive inflammatory response to the body and stimulating the formation of granulation tissue and angiogenesis. Since pharmacodermia is rare in dogs and reports of ozonized sunflower oil and ozone for treat pharmacodermia is are rare in the literature, this paper aimed to report the use of ozonized sunflower oil in the treatment of pharmacodermia in a young female Rottweiler dog assisted and treated at a private veterinary clinic in Garanhuns, Pernambuco, Brazil.

Case: A 2-year-old Rottweiler female, weighting $53.3 \mathrm{~kg}$ was attended at a private veterinary clinic in Garanhuns (Pernambuco - PE) with a history of dystocia. The dog was submitted to ovary-hysterectomy under general anesthesia. After anesthesia recovery was prescribed omeprazol (1 mg/kg, orally (P.O) SID for 10 days), cephalexin (20 mg/kg, P.O. BID for 10 days), tramadol hydrochloride (4 mg/kg, P.O. BID for seven days), carprofen ( $4.4 \mathrm{mg} / \mathrm{kg}$, P.O. SID for three days), and the use of Elizabethan collar. Furthermore, for topical treatment was described chlorhexidine digluconate $(0.2 \%)$ and ointment of allantoin and zinc oxide, SID, for 10 days. Seven days after the surgical procedure, the owner's dog reported by a telephone call the appearance of wounds in the dorsal region of the dog. Ten days after surgery, the dog returned to the veterinary clinic for stitches removal and wounds evaluation. During the physical examination, observed the presence of two cutaneous wounds, one located in the cervicothoracic region and the other wound was identified in the thoracic region and presence of pain during palpation. The wounds presented purulent secretion, pink coloration, and presence of necrosis. No changes were observed in the physiological parameters during the physical examination. The owner reported normophagia, ingestion of water, normal defecation and urine. The wound region was clipped, and prescribed topical chlorhexidine digluconate (2\%), allantoin with zinc oxide ointment every 8 hours, amoxicillin and clavulanate potassium $(20 \mathrm{mg} / \mathrm{kg}$, P.O. BID for 10 days), and dipyrone (20 $\mathrm{mg} / \mathrm{kg}$ P.O. BID for five days). Five days after the beginning of the second treatment the owner reported no improvement and the increased of the lesion, although the dog presented normophagia, ingestion of water, normal defecation, and urine. Thus, according to a therapeutic history of the use of cephalexin and amoxicillin with clavulanate potassium, both belongings to the $\beta$-lactamic antibiotic, the clinical diagnosis of pharmacodermia was determined. Wound cleaning and debridement were performed It has been recommended to suspend the previous treatment, and prescribed the use of ozonized sunflower oil (4 drops in each wound, BID) until the complete healing, associated to cleaning with ozonized ( $47 \mu \mathrm{g} / \mathrm{mL})$ saline solution $(0.9 \%)$. The sunflower oil contained linoleic acid (48-74\%) and oleic acid (14-39\%), and it was purchased directly from the supplier. Discussion: Thirty days after the treatment with ozonized sunflower oil, there was complete remission of the wounds Five months after the treatment the dog returned to clinical examination. No remnants of the wounds were observed and there were no changes in the physiological parameters or in the laboratory exams. According to the present report case, the use of ozone therapy using the ozonized sunflower oil and saline solution $(0.9 \%)$ is effective to treat wounds related to pharmacodermia.
\end{abstract}

Keywords: ozonized sunflower oil, skin, wound, small animals.

${ }^{1}$ Programa de Pós-graduação em Biotecnologia Animal, ${ }^{3}$ Departamento de Cirurgia e Anestesiologia Veterinária \& ${ }^{4}$ Programa de Pós-graduação em Animais Selvagens, Universidade Estadual Paulista (UNESP), Faculdade de Medicina Veterinária e Zootecnia (FMVZ), Botucatu, SP, Brazil. ${ }^{2}$ M.V. Autônomo, Botucatu. ${ }^{5}$ Programa de Pós-graduação em Anestesiologia, Faculdade de Medicina de Botucatu (FMB). ${ }^{6}$ Universidade Federal Rural de Pernambuco (UFRPE) Garanhuns, PE, Brazil. CORRESPONDENCE: J.I.S. Silva Júnior [ivaldo.almeidassj@ hotmail.com]. Programa de Pós-graduação em Biotecnologia Animal, FMVZ - UNESP. Distrito de Rubião Junior, s/n. CEP 18618-681 Botucatu, SP, Brazil. 


\section{INTRODUCTION}

Pharmacodermia is an adverse drug reaction which is manifested in the skin and mucous membranes [12]. The main drugs causing pharmacodermia are $\beta$-lactamic antibiotics [2]. It has rare occurrence in dogs and may present different clinical signs, including exfoliative erythema, rash, urticaria, edema, vesicle-bullous skin diseases, vasculitis and toxic epidermal necrosis [2,7].

Ozone gas is an unstable substance formed by three oxygen atoms and naturally found in the atmosphere in gaseous form [6]. It can be produced artificially through a high-powered ozone generator who turns the pure oxygen into ozone through electric unloading of high voltage and high frequency [8]. Ozone therapies are used to treat infectious, inflammatory and ischemic origin $[1,11,13,14]$.

The sunflower oil (Helianthus annuus) promotes wound healing and is used in wound treatment in diabetic patients [5,6]. A study used ozonized sunflower oil in wound treatment in the guinea pig (Cavia porcellus) and observed a complete remission of the wound in minor time and without collateral effects [11]. Another study reported the use of topical and rectal ozone therapy in untreated infected wounds in dogs (Canis lupus familiaris) [10].

Since pharmacodermatites are rare in dogs and reports of the use of ozonized sunflower oil for its treatment are rare in the literature. This paper aims to report the use of ozonized sunflower oil $(47 \mu \mathrm{g} / \mathrm{mL})$ and saline solution $(0.9 \%)$, in treatment of pharmacodermia in a young female Rottweiler attended and treated at a private veterinary clinic, in Garanhuns, Pernambuco, Brazil.

\section{CASE}

A 2-year-old Rottweiler female dog, weighting $53.3 \mathrm{~kg}$ was attended at a private veterinary clinic in Garanhuns (Pernambuco - PE) with a history of dystocia. The dog had given birth to four healthy puppies the previous night but one fetus with no heartbeat remained in the uterus, confirmed by abdominal ultrasonographic examination. The dog was submitted to ovary-hysterectomy under general anesthesia. Preanesthetic medication performed with ketamine ${ }^{1}[5 \mathrm{mg} / \mathrm{kg}$, intravenous (IV)], and tramadol hydrochloride ${ }^{2}$ [4 mg/ $\mathrm{kg}$, intramuscular (IM)], meloxicam ${ }^{3}$ [0.2 mg/kg, IV] was also administrated, aiming preemptive analgesia. Anesthetic induction performed with propofol ${ }^{4}[6 \mathrm{mg} /$ $\mathrm{kg}, \mathrm{IV}]$ and maintenance was with isoflurane ${ }^{5}$ in a closed anesthetic circuit. During the surgical procedure, the venous access of the cephalic vein was maintained with Ringer's infusion (Equiplex) ${ }^{6}$. No complications were observed during the surgical procedure. After anesthesia recovery was prescribed omeprazol ${ }^{2}[1 \mathrm{mg} /$ $\mathrm{kg}$, orally (P.O) SID for 10 days], cephalexin ${ }^{2}$ [20 mg/ $\mathrm{kg}$, P.O. BID for 10 days], tramadol hydrochloride ${ }^{2}$ [4 mg/kg, P.O. BID for 7 days], carprofen ${ }^{7}$ [4.4 mg/ $\mathrm{kg}$, P.O. SID for 3 days], and the use of Elizabethan collar $^{8}$. Furthermore, for topical treatment was described chlorhexidine digluconate ${ }^{2}[0.2 \%]$ and ointment of allantoin and zinc oxide ${ }^{1}$ [SID, for 10 days].

Seven days after the surgical procedure, the owner's dog reported by a telephone call the appearance of wounds in the dorsal region of the dog. Ten days after surgery, the dog returned to the veterinary clinic for stitches removal and wounds evaluation. During the physical examination, observed the presence of two cutaneous wounds, one located in the cervicothoracic region and measuring $25 \mathrm{~cm}$ width and $5 \mathrm{~cm}$ in length. The other wound was identified in the thoracic region with $15 \mathrm{~cm}$ width and $20 \mathrm{~cm}$ length, and presence of pain during palpation. The wounds presented purulent secretion, pink coloration, and presence of necrosis (Figure 1). No changes were observed in the physiological parameters during the physical examination. The owner reported normophagia, ingestion of water, normal defecation and urine.

The wound region was clipped, and prescribed topical chlorhexidine digluconate $(2 \%)$, allantoin with zinc oxide ointment every $8 \mathrm{~h}$, amoxicillin and clavulanate potassium ${ }^{9}$ [20 mg/kg, P.O. BID for 10 days], and dipyrone ${ }^{2}$ [20 mg/kg P.O. BID for 5 days].

Five days after the beginning of the second treatment the owner reported no improvement and the increased of the lesion, although the dog presented normophagia, ingestion of water, normal defecation, and urine. Thus, according to a therapeutic history of the use of cephalexin and amoxicillin with clavulanate potassium, both belongings to the $\beta$-lactamic antibiotic, the clinical diagnosis of pharmacodermia was determined.

After the physical examination, the patient underwent extensive clipped of the affected region and local treatment with saline solution $(0.9 \%)^{10}$ and the wounds were debrided (Figure 2). 
It has been recommended to suspend the previous treatment, and prescribed the use of ozonized sunflower oil ${ }^{11}$ [4 drops in each wound, BID] until the complete healing, associated to cleaning with ozonized $(47 \mu \mathrm{g} / \mathrm{mL})$ saline solution $0.9 \%$. The cleaning was performed using sterile gauze, without removal of scabs.

The sunflower oil contained linoleic acid (48$74 \%$ ) and oleic acid (14-39\%), and it was purchased directly from the supplier. The ozone gas used to ozonize the sunflower oil was obtained through a high-powered ozone generator which produces 480 grams of peroxide.

After the third day of treatment was observed the presence of granulation tissue and epithelial tissue (Figure 3). The owner reported absence of pain during palpation while the treatment where performed. Thirty days after the treatment with ozonized sunflower oil, there was complete remission of the wounds (Figure 4). Five months after the treatment the dog returned to clinical examination.

No remnants of the wounds were observed (Figure 5) and there were no changes in the physiological parameters or in the laboratory exams.

\section{DISCUSSION}

Due to increased use of substances with medical benefits and minimal side effects, as ozone therapy, new researches are carried out about its use in Medicine and Veterinary Medicine. Although ozone therapy in human patients is a common practice in different countries of Europe and Asia, even in Cuba [9]. Ozone therapy in Veterinary Medicine has excellent healing results with no side effects and it is considered a low-cost therapy [6].

The present case report described a case of pharmacodermia in a young female Rottweiler, caused probably by the use of cephalexin and amoxicillin with clavulanate potassium, both belonging to the $\beta$-lactamic antibiotics [2]. This group of drugs is reported as issue to cause pharmacodermia [2]. Since the pharmacodermia observed in the dog was associated to the use of these antibiotics the authors determinate to suspend all drugs prescribed [2] and started a topical ozone therapy.

The pharmacodermia observed in the present case was treated only with topical ozone therapy using ozonized sunflower oil and $(47 \mu \mathrm{g} / \mathrm{mL})$ ozonized saline solution $0.9 \%$, once it promotes wound healing

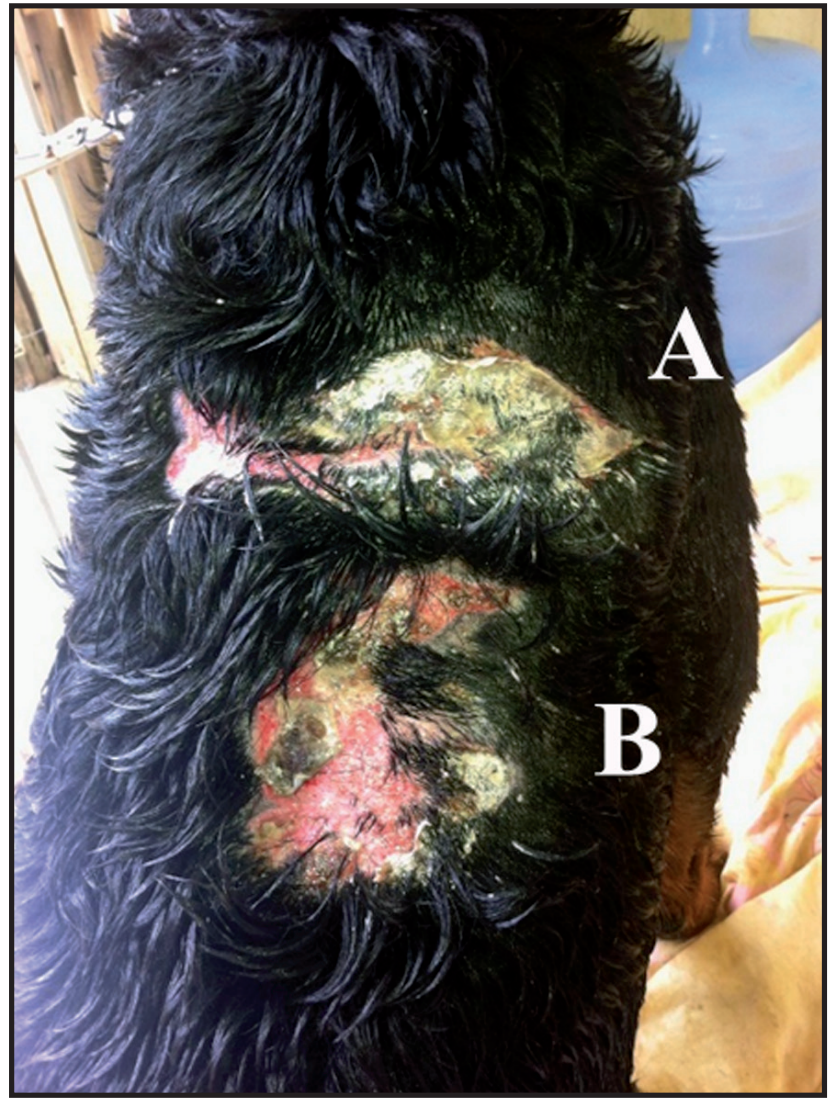

Figure 1. Two-year-old Rottweiler pharmacodermia, showing the presence of two cutaneous lesions (A and B) with purulent secretion, pink color and presence of necrosis. A- Wound was identified between the cervical and thoracic regions and was $25 \mathrm{~cm}$ long and $5 \mathrm{~cm}$ long. B- Wound was identified in the thoracic region and measured $15 \mathrm{~cm}$ wide and $20 \mathrm{~cm}$ long.

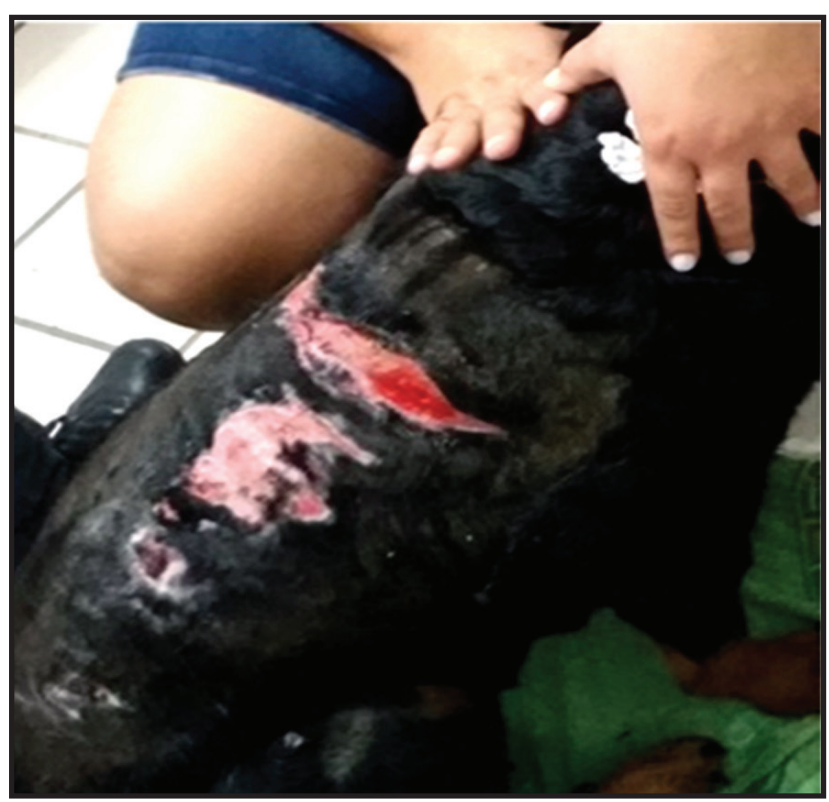

Figure 2. Wounds after the procedure of debridement of the bed and edges of the wounds.

including contaminated wounds $[1,5,6]$. The use of ozone gas in the sunflower oil potentiates the healing properties of the oil due the healing properties through the fatty acids present in sunflower oil $[5,6]$. A study 


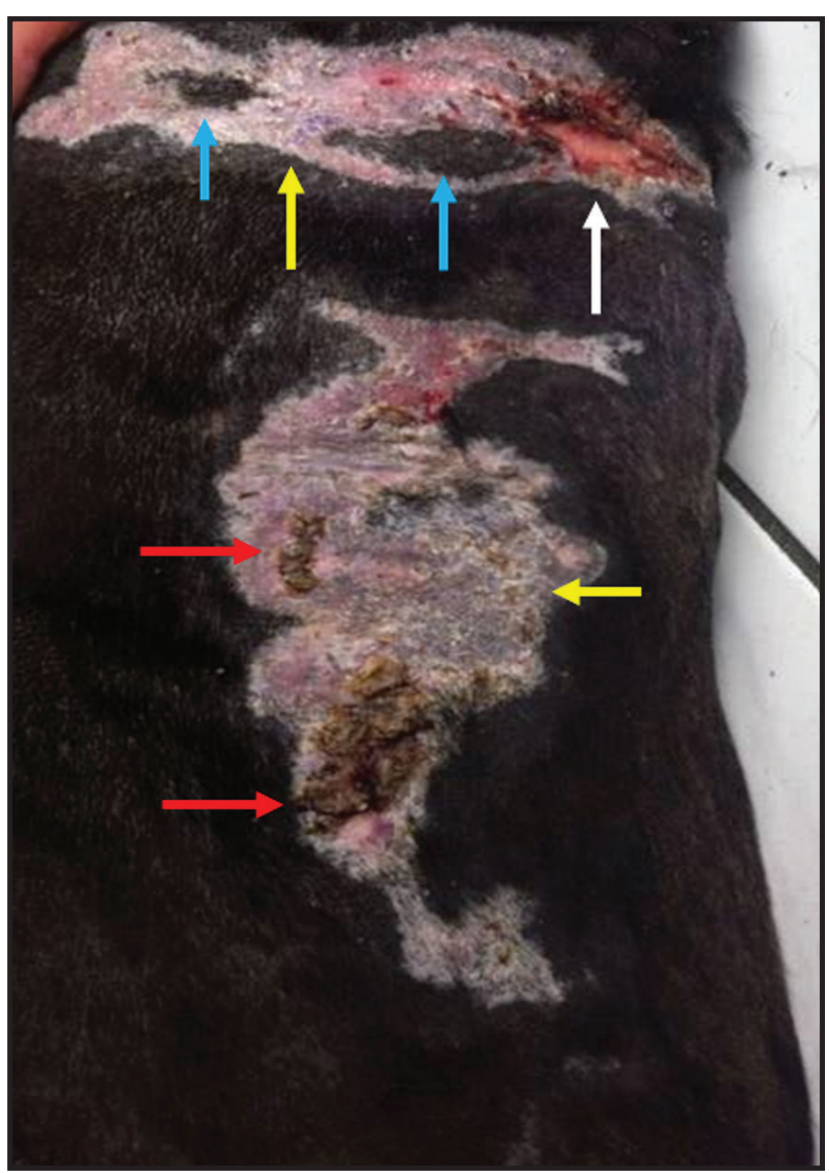

Figure 3. Wounds after the third day of treatment with ozonated saline solution $0.9 \%(47 \mu \mathrm{g} / \mathrm{mL})$ every $12 \mathrm{~h}$, and local application with ozonized sunflower oil (4 drops in each wound) and presence of tissue (white arrow), reepithelialization (yellow arrows), crusts (red arrows) and regions with hairs (blue arrows).

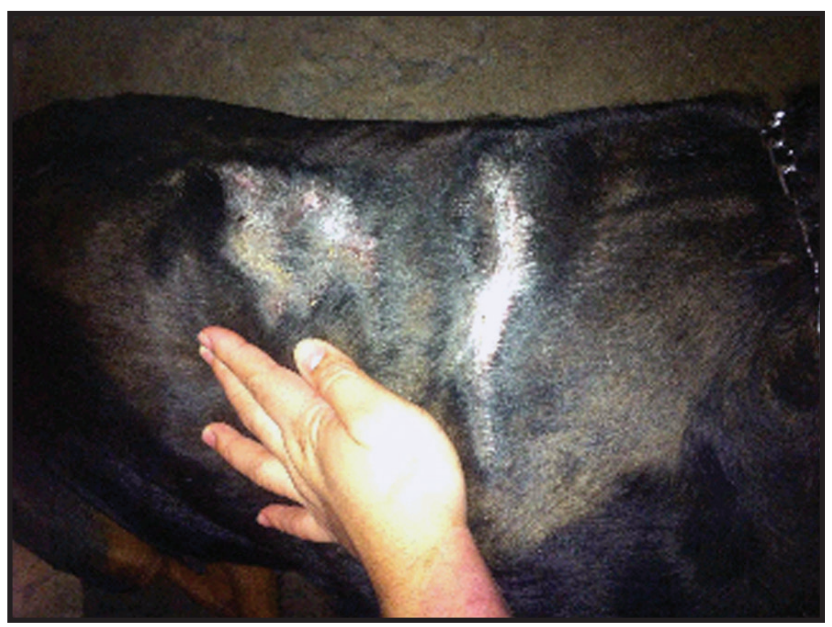

Figure 4. Wounds after 30 days of treatment with ozonated saline (47 $\mu \mathrm{g} / \mathrm{mL}$ ) every $12 \mathrm{~h}$, and local application with ozonized sunflower oil (4 drops in each wound).

with horses which were submitted to wound induction demonstrated a high efficacy in the healing process in wounds which treated with ozonized andiroba oil when compared to non-ozonized andiroba oil [3].

The debridement and topical use of ozonized sunflower oil and ozonized saline solution $(0.9 \%)$ was

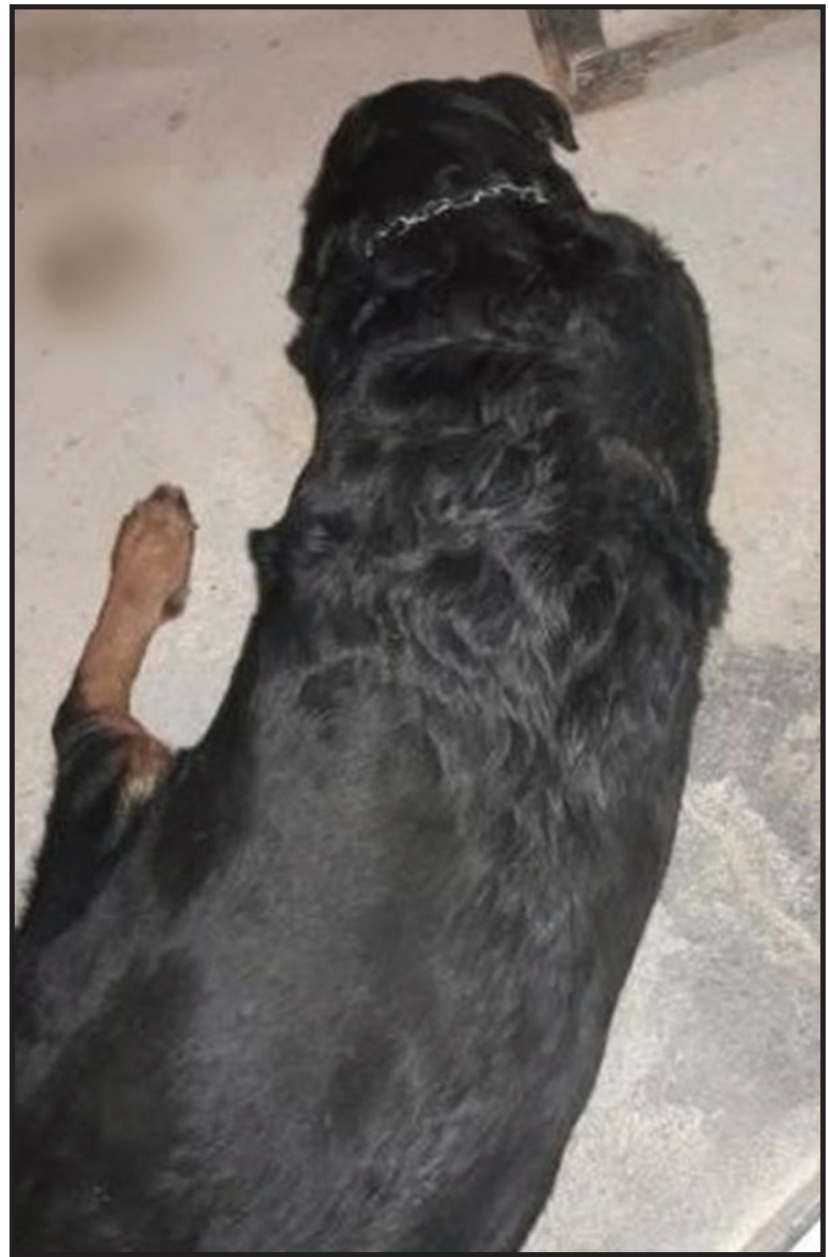

Figure 5. Rottweiler bitch, two years old, showing complete repilation of affected areas five months after the end of treatment with ozonized saline solution $0.9 \%(47 \mu \mathrm{g} / \mathrm{mL})$ every $12 \mathrm{~h}$, and application place with ozonized sunflower oil (4 drops on each wound).

able to accelerate the healing, and initiate the reepithelialization in a short period without use of other drugs. The efficacy of ozonized sunflower oil used to treat wounds in this case report was corroborated with the literature which identified positive results related to ozonized sunflower oil used in human patients [13].

It was possible to observe the presence of the granulation tissue, decrease of the inflammation and reepithelization of some areas on the third day of treatment with topical ozone therapy. In other study were observed the presence of granulation tissue, wound contraction and the decrease of wound area on the seventh day after the treatment of contaminated wounds in dog with ozonized sunflower oil associated with rectal ozone gas insufflation [10]. The same study observed the complete remission of the wounds 60 days after starting the treatment, differing from the present report case which was observed the complete remission of the wounds 30 days after starting the treatment. 
According to the present report case, the use of ozone therapy using the ozonized sunflower oil and saline solution $0,9 \%$ is effective to treat wounds related to pharmacodermia.

\section{MANUFACTURERS}

${ }^{1}$ Vetnil - Indústria e Comércio de Produtos Veterinários Ltda. Louveira, SP, Brazil.

${ }^{2}$ Laboratório Neo Química Comércio e Indústria. São Paulo, SP, Brazil.

${ }^{3}$ Medley Indústria Farmacêutica Ltda. Campinas, SP, Brazil. ${ }^{4}$ Claris - Produtos Farmacêuticos do Brasil Ltda. Barueri, SP, Brazil.
${ }_{5}^{5}$ Instituto BioChimico Indústria Farmacêutica Ltda. Itatiaia, RJ, Brazil.

${ }^{6}$ Isofarma Industrial Farmacêutica Ltda. Eusébio, CE, Brazil.

${ }^{7}$ Zoetis Industria De Produtos Veterinários Ltda. Campinas, São Paulo, Brazil.

${ }^{8}$ FuracãoPet. São Carlos, SP, Brazil.

${ }^{9}$ Aché Laboratórios Farmacêuticos S.A. Guarulhos, SP, Brazil.

${ }^{10}$ Eurofarma Laboratórios. São Paulo, SP, Brazil.

${ }^{11}$ VitaFisio. Recife, PE, Brazil.

Declaration of interest. The authors report no conflicts of interest. The authors alone are responsible for the content and writing of the paper.

\section{REFERENCES}

1 Associação Brasileira De Ozonioterapia - ABOZ. 2013. Informações que a sociedade europeia de ozonioterapia recomenda sejam dadas aos pacientes (Traduzida, revisada e acrescida com mais informações pela ABOZ - Associação Brasileira de Ozonioterapia). [www.aboz.org.br]. 7p.

2 Aleixo G.A.S, Coelho M.C.O.C, Silvestre L.S.A. \& Mota A.K.R. 2009. Farmacodermia em cães. Medicina Veterinária. 3(3): 31-35.

3 Araújo A.L. 2005. Efeitos do uso tópico do óleo de andiroba puro e ozonizado 16 em feridas cutâneas experimentalmente induzidas em equinos. 64f. Vila Velha, ES. Dissertação (Mestre em Ciência Animal) - Programa de Pós-graduação em Ciência Animal, Universidade Vila Velha.

4 Braz J.R.C. 2005. Fisiologia da termorregulação normal. Revista Neurociências. 13(3): 12-17.

5 Duarte D.A., Brandão D.S. \& Silva L.J.S. 2010. Óleo de girassol: alternativa na cicatrização de feridas. Relato de experiência. CESEP - Centro Superior de Ensino e Pesquisa de Machado. Revista Eletrônica Acervo Saúde. pp.1-1. [http://www.conferencias.ulbra.br/index.php/fpu/xvi/paper/viewFile/4737/2270].

6 Ferreira A.M., Souza B.M.V., Rigotti M.A. \& Loureiro M.R.D. 2012. Utilização dos ácidos graxos no tratamento de feridas: uma revisão integrativa da literatura nacional. Revista da Escola de Enfermagem da USP. 46(3): 752-60.

7 Guimarães C.D.O., Carvalho, C.V.C., Aires, E.M.O., Carneiro M.J.C., David M.B.M. \& Moreira L.F.M. 2018. Farmacodermia em cão da raça Dálmata: Relato de caso. Pubvet. 12(3): 1-5.

8 Hincapié A., Alves M.G., Melo G.A.E \& Canesin C.A. 2014. Conversor de pulsos elétricos de alta tensão em elevada frequência, para geração de ozônio. In: Anais do XX Congresso Brasileiro de Automática (Belo Horizonte, Brasil). pp 569-576.

9 Morette D.A. 2011. Principais aplicações terapêuticas da ozonioterapia. 19f. Botucatu, SP. Trabalho de Conclusão de Curso de Graduação (Medicina Veterinária) - Faculdade de Medicina Veterinária e Zootecnia da Universidade "Júlio de Mesquita Filho".

10 Pereira B.A., Caliari C. \& Kosachenco B.G. 2016. Ozonioterapia no tratamento de ferida em cão - relato de caso. In: Resumos do XVI Fórum de Pesquisa Científica e Tecnológica (Canoas, Brasil). 1p. [http://asmec.br/biblioteca/ anais2010/039.pdf].

11 Sanchez C.M.S. 2008. A utilização do óleo ozonizado para o tratamento tópico de lesões em porquinho da índia (Cavia porcellus)- relato de caso. 38f. Itaiba, SP. Especialização (Especialista em Clínica Médica e Cirúrgica de Animais Selvagens). Universidade Castelo Branco.

12 Santos F.P., Quitério L.M., Pinto V.B. \& Gomes L.B. 2015. Farmacodermia: Identificação dos tipos, medicamentos envolvidos e classes farmacológicas que acometem pacientes internados na clínica dermatológica. Revista Brasileira de Farmácia Hospitalar e Serviços de Saúde de São Paulo. 6(12): 12-17.

13 Oliveira J.T.C. 2007. Revisão sistemática de literatura sobre o uso terapêutico do ozonio em feridas. 256f. São Paulo, SP. Dissertação (Mestrado em Enfermagem) - Programa de Pós-graduação em Saúde do Adulto, Universidade de São Paulo.

14 Vilarindo M.C, Andreazzi M.A \& Fernandes V.S. 2013. Considerações sobre o uso 14 da ozonioterapia na clínica veterinária. In: Resumos do VIII EPCC - Encontro Internacional de Produção Científica Cesumar (Maringá, Brasil). Maringá: Editora CESUMAR, pp.1-9.

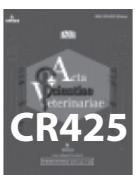

